Article

\title{
Prediction Model of Soleus Muscle Depth Based on Anthropometric Features: Potential Applications for Dry Needling
}

\author{
Juan Antonio Valera-Calero ${ }^{1,2, * \mathbb{C}}$, Ladislao Laguna-Rastrojo ${ }^{3}$, Fernando de-Jesús-Franco ${ }^{4}$, \\ Eduardo Cimadevilla-Fernández-Pola ${ }^{1}$, Joshua A. Cleland ${ }^{5}$, César Fernández-de-las-Peñas ${ }^{6,7}$ (i) \\ and José Luis Arias-Buría 6,7 (D) \\ 1 Department of Physiotherapy, Faculty of Education and Health, Universidad Camilo José Cela, Villanueva \\ de la Cañada, 28692 Madrid, Spain; ecimadevilla@ucjc.edu \\ 2 Escuela Internacional de Doctorado, Universidad Rey Juan Carlos, 28933 Alcorcón, Spain \\ 3 Private Professional Practice, Madrid, Spain; ladislao.laguna@alumno.ucjc.edu \\ 4 Department of Pharmacy, Faculty of Health Sciences, Alfonso X el Sabio University, Villanueva de la Cañada, \\ 28691 Madrid, Spain; fdejesus@uax.es \\ 5 Doctor of Physical Therapy Program, Department of Public Health and Community Medicine, Tufts \\ University School of Medicine, Boston, MA 02155, USA; clelandj@franklinpierce.edu \\ 6 Department of Physical Therapy, Occupational Therapy, Rehabilitation and Physical Medicine, Universidad \\ Rey Juan Carlos, 28933 Alcorcón, Spain; cesar.fernandez@urjc.es (C.F.-d.-1.-P.); \\ joseluis.arias@urjc.es (J.L.A.-B.) \\ 7 Cátedra Institucional en Docencia, Clínica e Investigación en Fisioterapia: Terapia Manual, Punción Seca y \\ Ejercicio Terapéutico, Universidad Rey Juan Carlos, 28933 Madrid, Spain \\ * Correspondence: javalera@ucjc.edu; Tel.: +34-653-766-841
}

Received: 28 March 2020; Accepted: 5 May 2020; Published: 7 May 2020

check for updates

\begin{abstract}
This study was conducted to investigate if anthropometric features can predict the depth of the soleus muscle, as assessed with ultrasound imaging, in a sample of healthy individuals to assist clinicians in the application of dry needling. A diagnostic study to calculate the accuracy of a prediction model for soleus muscle depth, as assessed with ultrasonography, in the middle-third and distal-third of the calf, based on anthropometric features such as age, height, weight, body mass index (BMI), calf length, mid-third and distal-third calf girth, was conducted on 48 asymptomatic healthy subjects $(75 \%$ male) involving a total of 96 calves. Multiple linear regression analyses were used to determine which variables contributed significantly to the variance in the soleus muscle depth at middle-third and distal-third of the calf by gender. Women were found to have a deeper soleus muscle than men $(p<0.001)$. Weight, height, BMI, and mid-third calf perimeter explained $69.9 \%$ of variance in men, whereas mid-third calf perimeter, calf length, height, and distal-third calf girth explained $73 \%$ of the variance in women of the distal-third soleus depth $(p<0.001)$. Additionally, mid-third calf girth and calf length explained $28.8 \%$ of variance in men, whereas mid-third calf perimeter, calf length, and weight explained $67.8 \%$ of variance in women of the mid-third soleus depth $(p<0.001)$. This study identified anthropometric features that predict soleus muscle depth, as assessed with ultrasound, in asymptomatic individuals, but these features are different in men and women. Our findings could assist clinicians in choosing the proper length of the needle to avoiding passing through the soleus during dry needling.
\end{abstract}

Keywords: soleus muscle; ultrasound; depth; anthropometric; gender 


\section{Introduction}

The soleus is a wide and flattened muscle located in the posterior compartment of the calf deep to the gastrocnemius muscles. The soleus muscle originates from the soleal line and middle third of the posterior aspect of the tibia, the proximal fourth third of the posterior surface of the fibula, and the posterior aspect of the fibular head and inserts, with the gastrocnemius, into the posterior part of the calcaneus forming the Achilles tendon [1]. Chow et al. reported a $2 \mathrm{~cm}$ mean thickness of the soleus muscle, with males exhibiting greater muscle thickness in general [2]. The soleus muscle contributes, with the gastrocnemius muscles, to ankle plantar-flexion, but also provides postural control of the ankle, particularly in weight bearing, since it controls ankle dorsiflexion when acting eccentrically.

Any musculoskeletal impairment in the soleus muscle could lead to biomechanical changes in the ankle. One common muscular impairment observed in the lower extremity are myofascial trigger points (TrPs). A TrP is defined as a sensitive spot in a skeletal muscle taut band that is painful on stimulation (e.g., manual palpation, muscle contraction, needling), elicits referred pain, and induces motor disturbances [3]. Trigger points can be considered active or latent depending on their ability to reproduce pain symptoms. Latent TrPs are asymptomatic from a sensory point of view but they promote motor disturbances, including restricted range of motion, muscle weakness, or accelerated fatigability [4]. Previous studies have reported a prevalence of latent TrPs in the soleus muscle ranging from $15 \%$ to $25 \%$ in asymptomatic people [5,6]. Similarly, Bajaj et al. [7] observed a prevalence of $15-20 \%$ of latent $\mathrm{TrPs}$ in the soleus muscle in a sample of patients with lower limb osteoarthritis. There is preliminary evidence suggesting a potential relationship between latent $\operatorname{TrPs}$ in the soleus muscle and restricted ankle range of motion; therefore, its management seems highly relevant for some sports [8]. In fact, an adequate ankle range of motion is necessary for functional activities such as running, gait, or ascending-descending stairs [9].

Previous studies have investigated the effects of $\operatorname{TrP}$ manual therapy of the triceps surae, which includes the soleus muscle, in individuals with plantar heel pain [10], calf pain [11] or recreational athletes [8]. All studies reported positive results in pain and mobility outcomes with the application of manual therapy; however, it should be considered that manual access to the soleus muscle is only possible on the lateral portion due to its anatomical location. This is the reason why some authors had advocated for the use of dry needling for proper targeting of the soleus [12]. The American Physical Therapy Association (APTA) defines dry needling as "an intervention using a thin filiform needle that stimulates the skin, TrPs, muscle or connective tissue for the treatment of musculoskeletal pain disorders" [13]. This intervention consists of the insertion of a solid filiform needle into a muscle with the aim to inactivate potential TrPs [12]. Since the soleus is located deep in the gastrocnemius muscles, the use of a 40 or $50 \mathrm{~mm}$ needle is usually recommended for penetrating this muscle. In fact, the length of the needle is commonly determined based on patient's anthropometric features. It is important to be aware of the anatomical location of the posterior tibial nerve through the posterior compartment of the calf behind the soleus muscle [12], because crossing throughout the soleus muscle with the needle could lead to potential trauma to the tibial nerve. The tibial nerve is a main branch of the sciatic nerve which arises at the apex of the popliteal fossa. When the nerve travels through the popliteal fossa, it passes deep in the tendinous arch of the soleus muscle, usually at the mid-line, to enter the posterior compartment of the calf. In the calf, the nerve runs downwards and medially to the mid-line to finally reach the posteromedial side of the ankle [14].

Although most adverse events with dry needling are minor [15], potential damage of a nerve is possible in some cases [16]. In fact, different strategies have been proposed to optimize the patient's safety and relative risk when performing dry needling. For instance, Ball et al. [17] have recently suggested that patient positioning can help to reduce the risk of puncturing the femoral nerve when dry needling the iliacus muscle. Others proposed the use of ultrasound imaging to reduce the number of adverse events during needling interventions [18]. Nevertheless, the use of ultrasound imaging during dry needling is not always possible due to the orientation of the needle in relation to the muscle 
and the probe. Additionally, ultrasound equipment is operator-dependent and involves economic costs [19].

Ferrer-Peña et al. [20] have recently developed a prediction model, based on forearm anthropometric measures, determining the necessary needle length to prevent median nerve injury during the application of dry needling on the pronator teres. A similar procedure could help clinicians to determine the soleus depth for necessary minimizing the risk of puncturing the posterior tibial nerve. Therefore, the aim of this study was to investigate if anthropometric features can predict the depth of the soleus muscle, as assessed with ultrasound imaging, in a sample of healthy individuals. We hypothesized that a prediction model based on anthropometric features of the calf would accurately predict the depth of the soleus muscle and could assist during the application of dry needling interventions in this muscle. Since gender differences are found in the soleus [2], we analyzed the prediction model in men and women separately.

\section{Methods}

\subsection{Study Design}

A diagnostic study to calculate the prediction model accuracy for soleus muscle depth, as assessed with ultrasonography, in the mid-third and distal-third of the calf based on anthropometric features such as age, height, weight, body mass index (BMI), gender, calf length, half-third and distal-third calf girth, was conducted. This study followed the Standards for the Reporting of Diagnostic Accuracy Studies (STARD) guidelines and checklist [21].

\subsection{Participants}

Consecutive healthy volunteers recruited from local flyer announcements located at a private clinic of Alfonso X El Sabio University between January-February 2020 were invited to participate. To be eligible to participate, volunteers had to be between 18 and 55 years old and have no report of pain in the lower extremity the previous year. Exclusion criteria included a prior history of recurrent pain in the lower extremity; any pharmacological treatment affecting muscle tone, e.g., muscle relaxants, analgesics; prior history of lower extremity surgery; lumbar radiculopathy or myelopathy; and any medical condition such as tumour or fracture. The study was approved by the Institutional Ethics Committee of Alfonso X El Sabio University (UAX 10-01-2020). Participants signed written informed consent prior to their inclusion in the study.

Anthropometric data included age, gender, height, weight, calf dominance and BMI [22]. Further, calf length (measured from the popliteal fossa to the calcaneal tuberosity) and calf girth (assessed in the mid-third and distal-third distance of the calf length) were also calculated (Figure 1).

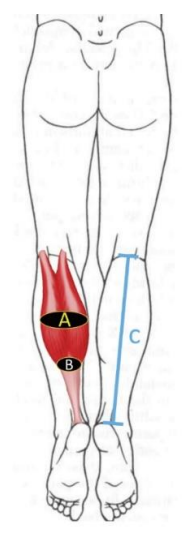

Figure 1. Anthropometric features assessed on the calf: (A) Calf girth assessed in the mid-third of the calf; (B) Calf girth assessed in the distal -third of the calf; (C) Calf length (measured from the popliteal fossa to the calcaneal tuberosity). 


\subsection{Soleus Ultrasound Procedure}

Subjects were placed in the prone position with their knees extended and 0 degrees of ankle dorsiflexion for both anthropometric and ultrasound measurements. A rigid table was placed on the foot surface of participants to assist in maintaining the ankle position. All ultrasound measurements were conducted by a clinician with more than 10 years of experience using ultrasound imaging. Soleus depth was measured in the middle-third and the distal-third of the calf by using an ultrasound equipment Alpinion Ecube i8 (Gyeonggi-do, Korea) with a linear transducer E8-PB-L3-12T 3-12 MHz. The thickness measurement between the skin and the lowest limit of the soleus muscle was performed (Figure 2). The mean of three repeated trials was calculated for the main analysis.

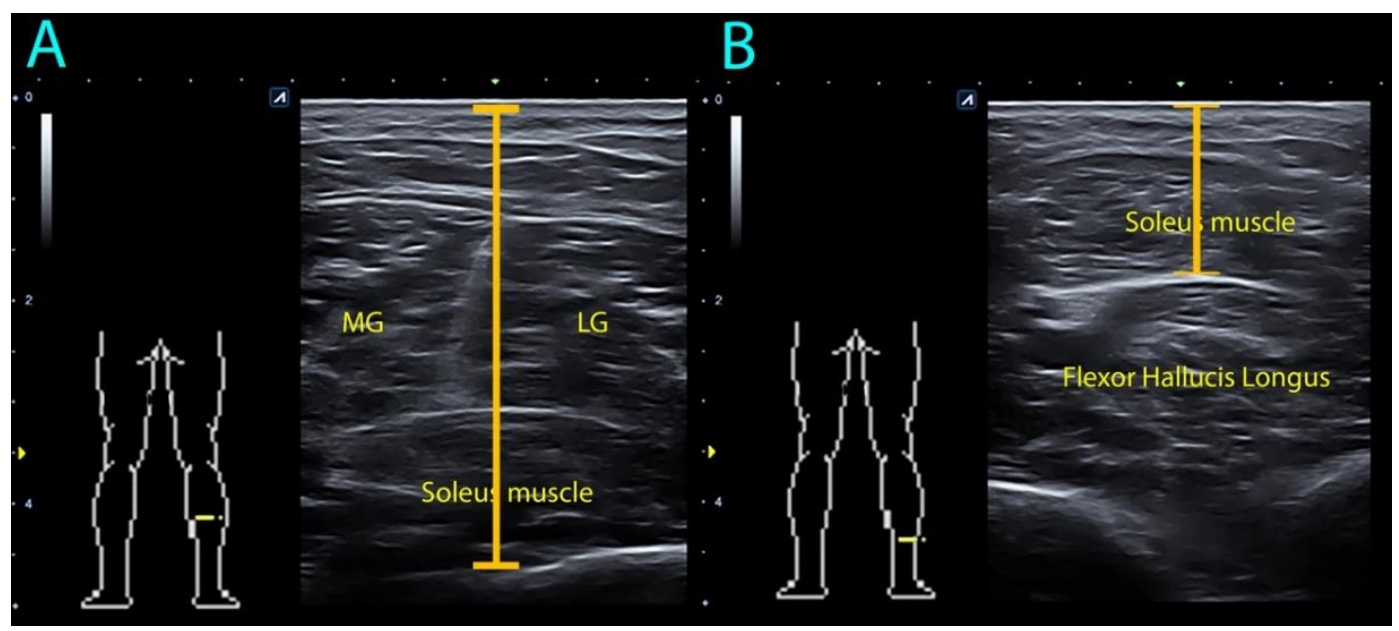

Figure 2. Ultrasound assessment of soleus muscle depth in the (A) mid-third and (B) distal-third of the calf. MG: medial gastrocnemius; LG: lateral gastrocnemius.

\subsection{Sample size Calculation}

Based on the only previous similar study [20], a sample size of at least 65 calves could be considered as appropriate. If we considered our design as a prognostic study, a range from 10 to 15 subjects per potential predictor, with no more than five predictor variables, is usually recommended to develop an adequate sample size for prediction models and for avoiding overestimation of the results [23]. Based on this alternative calculation a sample size of 50 calves would be required given the maximum cut-off of five predictors included in the final model. Since we originally include eight potential anthropometric features in the model, we calculated a sample size of at least 80 calves.

\subsection{Statistical Analysis}

Data analysis was conducted with the Statistical Package for the Social Science (SPSS) Version 21 (Armonk, NY, USA) for Mac OS. Normal distribution of the data was analyzed using the Kolmogorov-Smirnoff test $(p>0.05)$. After checking the sample homogeneity, Student $t$-tests for independent samples were used to determine gender and dominance differences. Multiple linear regression analyses were used to determine which variables contributed significantly to the variance in the soleus muscle depth at the middle-third and distal-third of the calf.

First, a correlation analysis between soleus depth and anthropometric features was performed using Pearson's correlation coefficients $(r)$ for normal distributed variables. Values of $<0.3$ were considered a poor correlation, from 0.3 to 0.5 a fair correlation, 0.6 to 0.8 a moderate correlation, and $>0.8$ a strong correlation [24]. Those variables that were statistically significant $(p<0.05)$ were included in a stepwise multiple linear regression model to estimate the proportion of variance explaining soleus muscle depth. The Pearson correlation coefficients were also applied to identify 
multicollinearity and shared variance between the variables (defined as $r>0.80$ ). All correlation analyses were conducted in men and women, separately.

Hierarchical regression models were conducted to determine those variables that contributed significantly to soleus depth at each point, separately in men and women. The significance criterion of the critical $F$ value for entry into the regression equation was set at $p<0.05$. The adjusted changes in $R^{2}$ were reported after each step of the regression model to determine the association of each additional variable in the regression model.

\section{Results}

From a total of 50 volunteers responding to the announcement, two were excluded due to previous calf trauma. Forty-eight asymptomatic subjects $(75 \%$ men) were included ( $n=96$ calves). Table 1 summarizes the demographic and anthropometric data of the sample, by gender and calf dominance (right). Men were younger, taller and heavier, and have had longer calf length and more superficial soleus muscles than women (all, $p<0.001$ ). No significant differences by calf dominance were observed.

Table 2 describes Pearson's correlation coefficients between anthropometric features and soleus depth. Soleus depth, either at distal-third or mid-third calf point, was positively correlated with anthropometric features, except age, in both men and women. In addition, significant correlations also existed among the independent anthropometric variables with no multicollinearity; therefore, each variable was included in the regression analyses.

Table 3 shows the hierarchical regression analysis conducted in this study in men. For distal-third soleus depth, BMI contributed $27.7 \%$ of the variance $(p<0.001)$, weight contributed an additional $29.1 \%$ $(p<0.001)$, height an additional $10.2 \%(p<0.001)$, and mid-third calf perimeter the last $2.9 \%$ of variance $(p=0.008)$. When combined, anthropometric features explained $69.9 \%$ of the variance of distal-third soleus depth in men $(p<0.001)$. For mid-third soleus depth, mid-third calf girth contributed $15.4 \%$ of variance $(p<0.001)$ and calf length contributed an additional $13.4 \%(p<0.001)$. When combined, anthropometric features explained $28.8 \%$ of the variance of mid-third soleus depth in men (Table 3 ).

Table 4 shows the hierarchical regression analysis in women. For distal-third soleus depth, mid-third calf girth contributed $49.8 \%$ of the variance $(p<0.001)$, calf length contributed an additional $4 \%(p=0.038)$, height an additional $9.4 \%(p=0.002)$, and distal-third calf girth $9.8 \%$ of the variance $(p=0.008)$. When combined, anthropometric features explained $73 \%$ of the variance in the distal-third soleus depth in women. For mid-third soleus depth, mid-third calf girth contributed $56.1 \%$ of variance $(p<0.001)$, calf length contributed an additional $11 \%(p<0.001)$, and weight the last $0.7 \%(p=0.013)$. When combined, anthropometric features explained $67.8 \%$ of the variance of mid-third soleus depth in women (Table 4). 
Table 1. Anthropometric features and soleus muscle depth of the total sample and by gender.

\begin{tabular}{|c|c|c|c|c|c|c|c|c|c|c|}
\hline & $\begin{array}{l}\text { Subjects } \\
\text { (calves) }\end{array}$ & Age (years) & Height (m) & Weight (kg) & $\begin{array}{c}\text { BMI } \\
\left(\mathrm{kg} / \mathrm{m}^{2}\right)\end{array}$ & $\begin{array}{l}\text { Calf Length } \\
\text { (cm) }\end{array}$ & $\begin{array}{l}\text { Distal Third } \\
\text { Calf Perimeter } \\
\text { (cm) }\end{array}$ & $\begin{array}{l}\text { Mid-Third } \\
\text { Calf Perimeter } \\
\text { (cm) }\end{array}$ & $\begin{array}{l}\text { Distal- Third } \\
\text { Soleus Depth } \\
\text { (cm) }\end{array}$ & $\begin{array}{l}\text { Mid-Third } \\
\text { Soleus Depth } \\
\text { (cm) }\end{array}$ \\
\hline Sample & 48 & $26.0 \pm 7.0$ & $1.75 \pm 0.1$ & $76.0 \pm 16.0$ & $24.0 \pm 3.8$ & $43.8 \pm 2.5$ & $25.0 \pm 2.5$ & $31.6 \pm 3.1$ & $2.2 \pm 0.5$ & $3.5 \pm 0.5$ \\
\hline \multicolumn{11}{|l|}{ Gender } \\
\hline Male & $36(n=72)$ & $24.5 \pm 5.5^{*}$ & $1.80 \pm 0.05^{*}$ & $80.5 \pm 14.0 *$ & $24.7 \pm 3.7^{*}$ & $44.6 \pm 2.2^{*}$ & $25.0 \pm 2.2$ & $31.5 \pm 2.9$ & $2.1 \pm 0.4^{*}$ & $3.4 \pm 0.4$ * \\
\hline Female & $12(n=24)$ & $30.0 \pm 9.5$ & $1.70 \pm 0.05$ & $62.0 \pm 12.5$ & $21.6 \pm 3.2$ & $41.3 \pm 1.6$ & $25.5 \pm 3.2$ & $32.0 \pm 3.9$ & $2.5 \pm 0.5$ & $4.0 \pm 0.7$ \\
\hline \multicolumn{11}{|l|}{ Dominance } \\
\hline Dominant & $24(n=48)$ & $26.0 \pm 7.0$ & $1.75 \pm 0.1$ & $76.0 \pm 16.0$ & $24.0 \pm 3.8$ & $43.6 \pm 2.7$ & $25.4 \pm 2.5$ & $32.0 \pm 3.0$ & $2.2 \pm 0.5$ & $3.6 \pm 0.5$ \\
\hline Non-dominant & $24(n=48)$ & $26.0 \pm 7.0$ & $1.75 \pm 0.1$ & $76.0 \pm 16.0$ & $24.0 \pm 3.8$ & $43.9 \pm 2.5$ & $24.9 \pm 2.5$ & $31.5 \pm 3.3$ & $2.2 \pm 0.5$ & $3.5 \pm 0.6$ \\
\hline
\end{tabular}


Table 2. Pearson-Product Moment Correlation Matrix.

\begin{tabular}{|c|c|c|c|c|c|c|c|c|c|}
\hline & & 1 & 2 & 3 & 4 & 5 & 6 & 7 & 8 \\
\hline \multirow{8}{*}{ Men ( $n=72$ calves) } & 1. Distal-third soleus depth & & & & & & & & \\
\hline & 2. Mid-third soleus depth & $0.597 * *$ & & & & & & & \\
\hline & 4. Height & $0.411^{* *}$ & n.s. & n.s. & & & & & \\
\hline & 5. Weight & $0.307^{* *}$ & $0.272 *$ & n.s. & $0.474^{* *}$ & & & & \\
\hline & 6. BMI & $0.536^{* *}$ & $0.402^{* *}$ & n.s. & n.s. & $0.734^{* *}$ & & & \\
\hline & 7. Calf length & -0.281 * & $-0.245 *$ & n.s. & $0.829 * *$ & $0.500 * *$ & $0.232 *$ & & \\
\hline & 8. Distal-third calf girth & $0.389 * *$ & $0.295 *$ & n.s. & n.s. & $0.628 * *$ & $0.622 * *$ & $0.232 *$ & \\
\hline & 9. Mid-third calf girth & $0.430^{* *}$ & $0.407^{* *}$ & n.s. & n.s. & $0.772^{* *}$ & $0.776^{* *}$ & $0.289 *$ & $0.753^{* *}$ \\
\hline \multirow{8}{*}{ Women ( $n=24$ calves) } & 1. Distal-third soleus depth & & & & & & & & \\
\hline & 2. Mid-third soleus depth & $0.597^{* *}$ & & & & & & & \\
\hline & 3. Age & n.s. & n.s. & & & & & & \\
\hline & 5. Weight & $0.751^{* *}$ & $0.861^{* *}$ & n.s. & $0.624 * *$ & & & & \\
\hline & 6. BMI & $0.752^{* *}$ & $0.738^{* *}$ & n.s. & $0.671^{* *}$ & $0.773 * *$ & & & \\
\hline & 7. Calf length & $0.614^{* *}$ & $0.578^{* *}$ & n.s. & $0.723 * *$ & $0.645^{* *}$ & $0.777^{* *}$ & & \\
\hline & 8. Distal-third calf girth & $0.719^{* *}$ & $0.752^{* *}$ & n.s. & $0.537 * *$ & $0.704^{* *}$ & $0.728^{* *}$ & $0.624^{*}$ & \\
\hline & 9. Mid-third calf girth & $0.743^{* *}$ & $0.738^{* *}$ & n.s. & $0.493^{* *}$ & $0.638^{* *}$ & 0.790 ** & $0.608^{* *}$ & $0.778^{* *}$ \\
\hline
\end{tabular}

n.s. non-significant; ${ }^{*} p<0.05 ;{ }^{* *} p<0.01$. 
Table 3. Summary of the Regression Analyses to determine Predictors of Soleus Depth in Men.

\begin{tabular}{|c|c|c|c|c|c|c|c|}
\hline & Predictor Outcome & B & SE B & $95 \% \mathrm{CI}$ & $\beta$ & $\mathbf{t}$ & $\mathbf{P}$ \\
\hline \multirow{14}{*}{$\begin{array}{l}\text { Distal-third } \\
\text { soleus depth }\end{array}$} & Step 1 & & & & & & \\
\hline & BMI & 0.536 & 0.110 & $0.035,0.078$ & 0.056 & 2.631 & 0.0001 \\
\hline & Step 2 & & & & & & \\
\hline & BMI & 1.950 & 0.023 & $0.159,0.251$ & 0.205 & 9.931 & 0.0001 \\
\hline & Weight & 1.515 & 0.006 & $0.030,0.053$ & 0.041 & 6.937 & 0.0001 \\
\hline & Step 3 & & & & & & \\
\hline & BMI & 7.165 & 0.118 & $0.520,0.988$ & 0.754 & 6.417 & 0.0001 \\
\hline & Weight & 7.402 & 0.034 & $0.134,0.271$ & 0.203 & 5.890 & 0.0001 \\
\hline & Height & 2.148 & 0.031 & $0.085,0.208$ & 0.146 & 4.740 & 0.0001 \\
\hline & Step 4 & & & & & & \\
\hline & BMI & 7.373 & 0.113 & $0.551,1.001$ & 0.776 & 6.889 & 0.0001 \\
\hline & Weight & 7.885 & 0.033 & $0.149,0.282$ & 0.216 & 6.492 & 0.0001 \\
\hline & Height & 2.285 & 0.030 & $0.096,0.215$ & 0.156 & 5.329 & 0.0001 \\
\hline & Mid-third calf girth & 0.289 & 0.014 & $0.010,0.068$ & 0.039 & 2.719 & 0.008 \\
\hline \multirow{4}{*}{$\begin{array}{l}\text { Mid-third } \\
\text { soleus depth }\end{array}$} & $\begin{array}{c}\text { Step } 1 \\
\text { Mid-third calf girth }\end{array}$ & 0.407 & 0.015 & $0.027,0.088$ & 0.057 & 3.727 & 0.0001 \\
\hline & Step 2 & & & & & & \\
\hline & Mid-third calf girth & 0.521 & 0.015 & $0.044,0.103$ & 0.073 & 4.981 & 0.0001 \\
\hline & Calf length & -0.395 & 0.019 & $-0.108,-0.033$ & -0.071 & -3.776 & 0.0001 \\
\hline
\end{tabular}

Distal-third soleus depth: $R^{2}$ adj. $=0.277$ for step $1, R^{2}$ adj. $=0.568$ for step $2, R^{2}$ adj. $=0.670$ for step $3, R^{2}$ adj. $=0.699$ for step 4; Mid-third soleus depth: $R^{2}$ adj. $=0.154$ for step $1, R^{2}$ adj. $=0.288$ for step 2 .

Table 4. Summary of the Regression Analyses to determine Predictors of Soleus Depth in Women.

\begin{tabular}{|c|c|c|c|c|c|c|c|}
\hline & Predictor Outcome & B & SE B & $95 \%$ CI & $\beta$ & $\mathbf{t}$ & $\mathbf{P}$ \\
\hline \multirow{4}{*}{$\begin{array}{l}\text { Distal-third } \\
\text { soleus depth }\end{array}$} & $\begin{array}{c}\text { Step } 1 \\
\text { Mid-third calf girth }\end{array}$ & 0.843 & 0.016 & $0.084,0.150$ & 0.117 & 7.354 & 0.0001 \\
\hline & $\begin{array}{c}\text { Step } 2 \\
\text { Mid-third calf girth } \\
\text { Calf length }\end{array}$ & $\begin{array}{l}0.927 \\
0.239\end{array}$ & $\begin{array}{l}0.015 \\
0.006\end{array}$ & $\begin{array}{l}0.096,0.162 \\
0.001,0.027\end{array}$ & $\begin{array}{l}0.129 \\
0.014\end{array}$ & $\begin{array}{l}8.137 \\
2.100\end{array}$ & $\begin{array}{c}0.0001 \\
0.038\end{array}$ \\
\hline & $\begin{array}{c}\text { Step } 3 \\
\text { Mid-third calf girth } \\
\text { Calf length } \\
\text { Height }\end{array}$ & $\begin{array}{l}0.969 \\
0.459 \\
0.462\end{array}$ & $\begin{array}{l}0.005 \\
0.006 \\
0.044\end{array}$ & $\begin{array}{l}0.044,0.065 \\
0.013,0.039 \\
0.065,0.251\end{array}$ & $\begin{array}{l}0.055 \\
0.026 \\
0.158\end{array}$ & $\begin{array}{c}11.027 \\
4.159 \\
3.555\end{array}$ & $\begin{array}{l}0.0001 \\
0.0001 \\
0.0002\end{array}$ \\
\hline & $\begin{array}{c}\text { Step } 4 \\
\text { Mid-third calf girth } \\
\text { Calf length } \\
\text { Height } \\
\text { Distal-third calf } \\
\text { girth } \\
\end{array}$ & $\begin{array}{l}0.993 \\
0.864 \\
1.365 \\
0.764\end{array}$ & $\begin{array}{l}0.010 \\
0.006 \\
0.064 \\
0.013\end{array}$ & $\begin{array}{l}0.076,0.116 \\
0.037,0.061 \\
0.333,0.599 \\
0.044,0.099\end{array}$ & $\begin{array}{l}0.096 \\
0.049 \\
0.466 \\
0.072\end{array}$ & $\begin{array}{c}13.938 \\
8.366 \\
7.309 \\
5.407\end{array}$ & $\begin{array}{l}0.0001 \\
0.0001 \\
0.0001 \\
0.0001\end{array}$ \\
\hline \multirow{3}{*}{$\begin{array}{l}\text { Mid-third } \\
\text { soleus depth }\end{array}$} & $\begin{array}{c}\text { Step } 1 \\
\text { Mid-third calf girth }\end{array}$ & 0.807 & 0.014 & $0.120,0.195$ & 0.158 & 8.620 & 0.0001 \\
\hline & $\begin{array}{c}\text { Step } 2 \\
\text { Mid-third calf girth } \\
\text { Calf length }\end{array}$ & $\begin{array}{l}0.878 \\
0.450\end{array}$ & $\begin{array}{l}0.008 \\
0.024\end{array}$ & $\begin{array}{l}0.150,0.210 \\
0.148,0.249\end{array}$ & $\begin{array}{l}0.180 \\
0.198\end{array}$ & $\begin{array}{c}12.833 \\
8.272\end{array}$ & $\begin{array}{l}0.0001 \\
0.0001\end{array}$ \\
\hline & $\begin{array}{c}\text { Step } 3 \\
\text { Mid-third calf girth } \\
\text { Calf length } \\
\text { Weight }\end{array}$ & $\begin{array}{l}0.666 \\
0.259 \\
0.282\end{array}$ & $\begin{array}{l}0.119 \\
0.114 \\
0.016\end{array}$ & $\begin{array}{l}0.095,0.144 \\
0.037,0.192 \\
0.004,0.028\end{array}$ & $\begin{array}{l}0.119 \\
0.114 \\
0.016\end{array}$ & $\begin{array}{c}10.261 \\
3.081 \\
2.739\end{array}$ & $\begin{array}{c}0.0001 \\
0.0001 \\
0.013\end{array}$ \\
\hline
\end{tabular}

Distal-third soleus depth: $R^{2}$ adj. $=0.498$ for step $1, R^{2}$ adj. $=0.538$ for step $2, R^{2}$ adj. $=0.632$ for step $3, R^{2}$ adj. $=0.730$ for step 4; Mid-third soleus depth: $R^{2}$ adj. $=0.561$ for step $1, R^{2}$ adj. $=0.671$ for step $2, R^{2}$ adj. $=0.678$ for step 3 . 


\section{Discussion}

This study found some anthropometric feature predicting soleus muscle depth in asymptomatic individuals, but these features are different in men and women and also depend on the level (mid-third or distal-third of the calf) where the soleus is assessed. These findings could guide clinicians in the use of dry needling interventions by assisting the selection of the proper length of the needle to avoid crossing the soleus muscle and potentially damaging the tibial nerve.

This is the first study to develop a prediction model for calculating the anatomical depth of a muscle based on anthropometric and ultrasound measurements. Ferrer-Peña et al. [20] created a decision tree depending on forearm girth to recommend the needle size with a $100 \%$ safety of median nerve accidental puncture. This recommendation is acceptable if clinicians cannot use ultrasound equipment, but this model cannot determine muscle depth. This could result in needling approaches not considering muscle depth, such as that of the soleus, which could lead to an accidental nerve puncture of deeper neurovascular structures. The results of the current study support that the first parameter to consider to determine needle length is gender. We observed between-gender differences (mean of $5 \mathrm{~mm}$ ) in soleus depth, with women exhibiting a greater muscle depth than men. This was a surprising finding since men tend to have greater average muscle thickness and greater absolute strength than women; however, some gender differences in soleus architecture have previously been observed [2]. In fact, a deeper soleus in women could be related to the fact that women exhibit more adipose tissue than men. This hypothesis is supported by one study showing that, although men are heavier than women, they have a thinner fat layer in the calf region [25].

The variables with higher impact determining soleus depth were also slightly different between men and women. For instance, weight, height or BMI were more relevant in men than in women, whereas calf girth and calf length were more relevant in women. This maybe also be related to gender differences in fatty distribution and volume [26]. It seems that anthropometric features related to muscle physical demand, such as weight, height or BMI, are more relevant in men [27], which are usually more physically active than women, whereas anthropometric features more associated to volume, such as calf girth and length, are more relevant in women. It is also important to determine that the variables associated with soleus depth are also slightly different depending on the area of the calf (mid-third or distal-third of the calf) where the soleus muscle is assessed. Nevertheless, our data identified a robust model for distal-third soleus depth (explaining $70 \%$ of the variance) in both men and women.

\subsection{Clinical Implications}

Perhaps the most important findings are the results from the hierarchical regression analysis used to complete the prediction model to predict the distal-third soleus depth in men and women, which explained variances of $70 \%$ and $73 \%$, respectively. Clinicians can use, in the absence of ultrasound equipment, the measurement of BMI, weight, height and mid-third calf girth to determine the depth of the soleus muscle in men and mid-third calf girth, calf length, height and distal-third calf girth in women. The predictive model was only able to explain $28.8 \%$ of the variance in the mid-third of the calf in men with the variables of calf girth and calf length. However, in women the mid-third of the calf girth, calf length, and height explained $68.8 \%$ of the variance. These identified models could be of considerable value to clinicians who target the soleus muscle with dry needling techniques as this could assist with selecting appropriate needle length and, therefore, preventing tibial posterior nerve injuries. Nevertheless, calculation of all anthropometric features could be slightly time-consuming.

The results of the current study suggest that clinicians should use needles ranging from 25 to $40 \mathrm{~mm}$ in length for needling the soleus muscle with a posterior needle approach while keeping in mind that the muscle is deeper in women than in men. This information is clinically relevant since the tibialis posterior neurovascular package runs under the soleus muscle; therefore, using needles longer than $40 \mathrm{~mm}$ could be risk puncturing this muscle with a posterior approach. The current prediction model could help clinicians to identify patients for using short needles $(25-30 \mathrm{~mm})$ based 
on anthropometric features. Future cadaveric studies could help to further elucidate the validity of this model in other needling approaches of the soleus muscle, e.g., the medial one [12]

\subsection{Limitations}

Although the current study has shown promising results, potential limitations should be recognized. First, this prediction model was based on a sample of healthy subjects, not equally distributed between men and women. Larger sample sizes are needed to determine normative values of soleus muscle depth. Second, we only assessed the depth of the soleus muscle without considering the thickness of the muscle or the adipose tissue. It is possible that the gender differences found in the current study are due to these outcomes and should be addressed in future studies.

\section{Conclusions}

This study found that some anthropometric features predict soleus muscle depth, as assessed with ultrasound, in asymptomatic individuals with proper accuracy, but these features are different in men and women. Weight, height or BMI were more relevant in men, whereas calf girth and calf length were more relevant in women. Our findings could help clinicians in choosing the proper length of the needle and avoiding passing through the soleus during the application of dry needling procedures.

Author Contributions: Conceptualization, J.A.V.-C. and L.L.-R.; formal analysis, C.F.-d.-1.-P. and J.L.A.-B.; investigation, J.A.V.-C., L.L.-R., F.d.-J.-F. and E.C.-F.-P.; data curation, J.A.C. and J.L.A.-B.; writing-original draft preparation, J.A.V.-C.; writing-review and editing, J.A.C., C.F.-d.-l.-P. and J.A.V.-C.; supervision, J.A.C. and C.F.-d.-l.-P. All authors have read and agreed to the published version of the manuscript

Funding: This research received no external funding.

Conflicts of Interest: The authors declare no conflict of interest.

\section{References}

1. Doral, M.N.; Alam, M.; Bozkurt, M.; Turhan, E.; Atay, O.A.; Dönmez, G.; Maffulli, N. Functional anatomy of the Achilles tendon. Knee Surg. Sports Traumatol. Arthrosc. 2010, 18, 638-643. [CrossRef]

2. Chow, R.S.; Medri, M.K.; Martin, D.C.; Leekam, R.N.; Agur, A.M.; McKee, N.H. Sonographic studies of human soleus and gastrocnemius muscle architecture: Gender variability. Eur. J. Appl. Physiol. Occup. Physiol. 2000, 82, 236-244. [CrossRef]

3. Simons, D.G.; Travell, J.G.; Simons, L. Myofascial Pain and Dysfunction: The Trigger Point Manual, 3rd ed.; Wolters Kluwer: Philadelphia, PA, USA, 2019.

4. Ge, H.Y.; Arendt-Nielsen, L. Latent myofascial trigger points. Curr. Pain Headache Rep. 2011, 15, 386-392. [CrossRef] [PubMed]

5. Grieve, R.; Barnett, S.; Coghill, N.; Cramp, F. The prevalence of latent myofascial trigger points and diagnostic criteria of the triceps surae and upper trapezius: A cross sectional study. Physiotherapy 2013, 99, 278-284. [CrossRef] [PubMed]

6. Zuil-Escobar, J.C.; Martínez-Cepa, C.B.; Martín-Urrialde, J.A.; Gómez-Conesa, A. The prevalence of latent trigger points in lower limb muscles in asymptomatic subjects. PM R 2016, 8, 1055-1064. [CrossRef] [PubMed]

7. Bajaj, P.; Bajaj, P.; Graven-Nielsen, T.; Arendt-Nielsen, L. Trigger points in patients with lower limb osteoarthritis. J. Muscoskeletal Pain 2001, 9, 17-33. [CrossRef]

8. Grieve, R.; Cranston, A.; Henderson, A.; John, R.; Malone, G.; Mayall, C. The immediate effect of triceps surae myofascial trigger point therapy on restricted active ankle joint dorsiflexion in recreational runner: A crossover randomised controlled trial. J. Bodyw. Mov. Ther. 2013, 17, 453-461. [CrossRef] [PubMed]

9. You, J.Y.; Lee, H.M.; Luo, H.J.; Leu, C.C.; Cheng, P.G.; Wu, S.K. Gastrocnemius tightness on joint angle and work of lower extremity during gait. Clin. Biomech. 2009, 24, 744-750. [CrossRef] 
10. Renan-Ordine, R.; Alburquerque-Sendín, F.; de Souza, D.P.; Cleland, J.A.; Fernández-de-las-Peñas, C. Effectiveness of myofascial trigger point manual therapy combined with a self-stretching protocol for the man- agement of plantar heel pain: A randomized controlled trial. J. Orthop. Sports Phys. Ther. 2011, 41, 43-50. [CrossRef]

11. Grieve, R.; Barnett, S.; Coghill, N.; Cramp, F. Myofascial trigger point therapy for triceps surae dysfunction: A case series. Man. Ther. 2013, 18, 519-525. [CrossRef]

12. Dommerholt, J.; Fernandez-de-las-Peñas, C. Trigger Point Dry Needling: An Evidence and Clinical- Based Approach, 2nd ed.; Churchill Livingstone, Elsevier: London, UK, 2019.

13. APTA. Description of Dry Needling in Clinical Practice: An Educational Resource Paper; APTA Public Policy, Pract Prof Aff Unit: Alexandria, VA, USA, 2013.

14. Standring, S. Gray's Anatomy: The Anatomical Basis of Clinical Practice, 41st ed.; Elsevier: Amsterdam, The Netherlands, 2015.

15. Boyce, D.; Wempe, H.; Campbell, C.; Fuehne, S.; Zylstra, E.; Smith, G.; Wingard, C.; Jones, R. Adverse events associated with therapeutic dry needling. Int. J. Sports Phys. Ther. 2020, 15, 103-113. [CrossRef] [PubMed]

16. McManus, R.; Cleary, M. Radial nerve injury following dry needling. BMJ Case Rep. 2018. [CrossRef] [PubMed]

17. Ball, A.M.; Finnegan, M.; Koppenhaver, S.; Freres, W.; Dommerholt, J.; Mayoral Del Moral, O.; Bron, C.; Moore, R.; Ball, E.E.; Gaffney, E.E. The relative risk to the femoral nerve as a function of patient positioning: Potential implications for trigger point dry needling of the iliacus muscle. J. Man. Manip. Ther. 2019, 27, 162-171. [CrossRef] [PubMed]

18. Halle, J.S.; Halle, R.J. Pertinent dry needling considerations for minimizing adverse effects: Part two. Int. J. Sports Phys. Ther. 2016, 11, 810-819. [PubMed]

19. Whittaker, J.L.; Ellis, R.; Hodges, P.W.; OSullivan, C.; Hides, J.; Fernandez-Carnero, S.; Arias-Buria, J.L.; Teyhen, D.S.; Stokes, M.J. Imaging with ultrasound in physical therapy: What is the PT's scope of practice? A competency-based educational model and training recommendations. Br. J. Sports Med. 2019, 53, 1447-1453. [CrossRef] [PubMed]

20. Ferrer-Peña, R.; Calvo-Lobo, C.; Gómez, M.; Muñoz-García, D. Prediction model for choosing needle length to minimize risk of median nerve puncture with dry needling of the pronator teres. J. Manip. Physiol. Ther. 2019, 42, 366-371. [CrossRef] [PubMed]

21. Bossuyt, P.M.; Reitsma, J.B.; Bruns, D.E.; Gatsonis, C.A.; Glasziou, P.P.; Irwig, L.; Lijmer, J.G.; Moher, D.; Rennie, D.; de Vet, H.C.; et al. STARD 2015: An updated list of essential items for reporting diagnostic accuracy studies. BMJ 2015, 351, h5527. [CrossRef]

22. Nayate, A.P.; Nasrallah, I.M.; Schmitt, J.E.; Mohan, S. Using body mass index to predict needle length in fluoroscopy-guided lumbar punctures. AJNR Am. J. Neuroradiol. 2016, 37, 572-578. [CrossRef]

23. Beneciuk, J.M.; Bishop, M.D.; George, S.Z. Clinical prediction rules for physical therapy interventions: A systematic review. Phys. Ther. 2009, 89, 114-124. [CrossRef]

24. Chan, Y.H. Biostatistics 104: Correlational analysis. Singap. Med. J. 2003, 44, 614-619.

25. Weiss, L.W.; Clark, F.C. Ultrasonic protocols for separately measuring subcutaneous fat and skeletal muscle thickness in the calf area. Phys. Ther. 1985, 65, 477-481. [CrossRef] [PubMed]

26. Jürimäe, T.; Jürimäe, J.; Wallner, S.J.; Lipp, R.W.; Schnedl, W.J.; Möller, R.; Tafeit, E. Relationships between body fat measures by DXA and subcutaneous adipose tissue thickness measures by Lipometer in adults. J. Physiol. Anthropol. 2007, 26, 513-516. [CrossRef] [PubMed]

27. Esformes, J.I.; Narici, M.V.; Maganaris, C.N. Measurement of human muscle volume using ultrasonography. Eur. J. Appl. Physiol. 2002, 87, 90-92. [CrossRef]

(C) 2020 by the authors. Licensee MDPI, Basel, Switzerland. This article is an open access article distributed under the terms and conditions of the Creative Commons Attribution (CC BY) license (http://creativecommons.org/licenses/by/4.0/). 